\title{
Biologic therapies in rheumatic diseases: drug and anti-drug antibody levels and clinical efficacy
}

\author{
*Correspondence: stefania.lombardi@usInordovest.toscana.it \\ 'SSD Clinical Analysis and Immunoallergology, Massa Carrara, Italy. \\ ${ }^{2}$ Center for Rheumatology, Versilia, Italy. \\ ${ }^{3}$ Center for Rheumatology, Pontedera, Italy. \\ ${ }^{4}$ Center for Rheumatology, Pistoia, Italy. \\ ${ }^{5}$ Center for Rheumatology, Livorno, Italy. \\ ${ }^{6}$ SSD Rheumatology Massa Carrara, Italy.
}

Stefania Lombardi ${ }^{1 *}$, Cristina Bernardoni ${ }^{6}$, Daniela Bertolucci ${ }^{2}$, Riccardo Cecchetti ${ }^{3}$, Francesca De Giorgio ${ }^{4}$, GianLuigi Occhipinti ${ }^{5}$, Andrea Palagi', Gloria Bertacca ${ }^{1}$, Isabella Giannelli ${ }^{1}$, Elena Bonomi ${ }^{1}$, Marco Friggeri ${ }^{1}$ and Giancarlo Tartarelli ${ }^{6}$

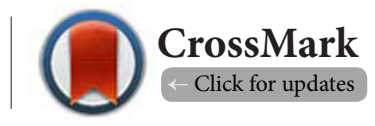

\begin{abstract}
Background: The aim of this study was to evaluate the relevance of drug and anti-drug antibody detection in the clinical management of patients with rheumatoid arthritis (RA) and spondyloarthropaties (SpA) in treatment with anti- tumor necrosis factor alpha (TNFa) biologics.

Methods and results: The study included 192 adult consecutive patients treated for at least 6 months with adalimumab (ADA) or etanercept (ETN) or infliximab (IFX); patients underwent clinical observations in the Rheumatologic Unit of 5 Hospitals in Tuscany. Their demographic and clinical characteristics to calculate DAS28 and BASDAI scores were collected. Drug levels and anti-drug antibodies (anti-drug $\mathrm{Ab}$ ) were evaluated immediately before drug injection or infusion. A total of 192 patients were studied: 62 receiving IFX, 64 ADA, and 66 ETN with a mean age of 57 years (range 18-86 years); the study group was composed of $51 \%$ women. Forty percent of the patients were affected by RA, $60 \%$ by SpA. Altogether, $81 \%$ of patients demonstrated therapeutic drug levels. Anti-drug Ab were found in 19\% of patients taking IFX, 10\% taking ETN and 5\% taking ADA. No significant correlation was found between anti-drug Ab presence and low drug levels, between anti-drug Ab and high DAS28 and BASDAI scores, as well as between low drug levels and high DAS28 and BASDAI scores.
\end{abstract}

Conclusions: Low drug levels were found in 19\% of the rheumatic patients and there were not correlations with presence of anti-drug Ab or patient's clinical status.

Keywords: Anti- tumor necrosis factor alpha (TNFa) biologics, anti drug antibodies, rheumatoid arthritis, spondyloarthropaties, drug levels

\section{Introduction}

ADA, ETN and IFX, all TNFa blockers, actually represent an important therapeutic aid for RA and SpA patients. In a third of cases such drugs are ineffective and this is due to primary treatment failure (drug inefficacy or serious side effects) or secondary treatment failure (drug loss of efficacy after initial good response). It has been shown that serum levels of ADA, ETN and IFX correlate with the clinical response in RA, while in ankylosing spondylitis (AS) data are controversial [1-4]. Similarly, anti-drug Ab levels inversely correlate with drugs levels and therapeutic response [4-6]. The mechanism of drug inactivation is linked to anti-drug Ab formation (against biological medications) which causes the neutralization of the drug and its increased clearance [5]: only $4 \%$ of patients with anti-adalimumab antibodies (anti-ADA Ab) achieved clinical remission compared to $34 \%$ anti-ADA Ab negative patients [6]. ETN has shown a less immunogenic effect with anti-etanercept antibodies (anti-ETN Ab) not detectable or present only in a low number of patients; as a consequence anti-ETN immune response has a minimal effect on clinical response [4,7-9]. A clinically relevant impact of anti-drug $A b$ is described in about half of the patients receiving repeated TNFa monotherapy and therefore immune suppression by concomitant administration of metrotrexate (MTX) is indicated in RA and SpA patients [8,10-21]. Detectable anti-drug Ab decrease TNFa blockers response by as much as $80 \%$ [22]. This has been shown with only one 
or two biologic treatments without comparing differences in patients suffering from different inflammatory diseases.

The aims of our study were: a) to assess the relationship between clinical response and TNFa blockers serum levels and anti-drug Ab concentrations in RA and SpA (AS and psoriatic arthritis (PsA)) patients treated with ADA, ETN, and IFX b) to verify if a single serological determination could be useful in clinical practice for patient management.

\section{Methods}

\section{Study population}

Between September 2014 and February 2015, consecutive patients with RA and SpA, that were treated with anti-TNFa biologics were invited to participate to the present study. $\mathrm{Pa}$ tients were followed by the Rheumatology Units of 5 Tuscany hospitals participating in the study. The study included 192 adults $\geq 18$ years who were treated with either ADA, IFX or ETN monotherapy or concomitant MTX therapy. Exclusion criteria were: patients treated with a different TNFa blocker or for less than 6 months. Written consent was obtained from all participants and the study was approved by the Ethics Committee of our hospital. Clinical data and blood samples were collected from patients just before they received a new intravenous or subcutaneous dose of the anti-TNFa agents. Samples were kept a $-20^{\circ} \mathrm{C}$ until processed.

\section{Assessment of disease activity}

RA disease activity was assessed using the 28-joint disease activity score (DAS28) (swollen joint count, tender joint count, ESR and general health) as described elsewhere [23]. The disease activity of SpA was assessed using the Bath ankylosing spondylitis disease activity index (BASDAI) on a 100-mm visual analogue scale as previously described [24].

\section{Definition of clinical response}

The clinical response to anti-TNFa treatment in RA patients was assessed using the EULAR response criteria [25]. Briefly, the criteria were: adequate response DAS28 $\leq 3.2$; moderate response DSA28 $\leq 5.1$; non adequate response DAS28 $>5.1$. For patients with $\mathrm{SpA}$ the criteria were: adequate response $B A S D A I \leq 2$; moderate response $B A S D A I \leq 4$; non adequate response $\mathrm{BASDAI}>4$.

\section{Dosage of the anti-TNFa agents}

The dosage of IFX was $3 \mathrm{mg} / \mathrm{Kg}$ per dose for RA and $5 \mathrm{mg} / \mathrm{Kg}$ for $\mathrm{SpA}$, given as intravenous infusion at baseline, week 2, 6, and then every 6-8 weeks. ETN was given subcutaneously at $50 \mathrm{mg}$ per dose every week. ADA was given subcutaneously at $40 \mathrm{mg}$ per dose every 2 weeks.

\section{Drug concentration and anti-drug antibody assays}

Serum drug levels and anti-drug Abs were evaluated immediately before next drug injection or infusion. Concentrations of free IFX and ADA were measured in serum samples by IDK monitor Infliximab or Adalimumab drug level ELISA, respectively, according to the manufacturer's instructions (Immunodiagnostik AG, Bensheim, Germany). Concentrations of serum free ETN were measured by Shikari Q-ETA (Matriks Biotek Laboratories, Israel). Briefly, standards and serum samples were incubated in the microtitre plate coated with the specific monoclonal anti-IFX or ADA or ETN antibody. Following incubation wells were washed and peroxidaselabeled anti-IFX or ADA or ETN specific antibody was added. After incubation, wells were washed and the bound enzymatic activity was detected by addition of chromogenic substrate. A dose response curve, specific for each biologic, was generated using the values obtained from standards. The concentrations of free biologic in the samples were determined directly from the curve. Results were express as $\mathrm{ng} / \mathrm{ml}$ for ADA and IFX and as $\mu \mathrm{g} / \mathrm{ml}$ for ETN. The ELISA detection limits were: $2.3 \mathrm{ng} /$ $\mathrm{ml}$ and $2.6 \mathrm{ng} / \mathrm{ml}$ for IFX and ADA assays respectively, and $0.2 \mu \mathrm{g} / \mathrm{ml}$ for ETN assay. No cross reactivity to other plasma proteins or anti TNFa-blockers, different from the investigated one, was reported.

The presence in serum samples of free human antibodies against IFX, ADA and ETN was detected by IDK monitor Infliximab or Adalimumab total ADA ELISA and IDK monitor Etanercept free ADA ELISA, respectively (Immunodiagnostik AG, Bensheim, Germany). Briefly, in the first incubation step the free anti-drug antibodies from the sample were bound to the drug coated on the plate. To remove all unbound substances, a washing step was carried out. In a further incubation step, peroxidase-labeled therapy antibody was added. After another washing step, to remove all unbound substances, the solid phase was incubated with chromogenic substrate. The optical density was directly proportional to the amount of bound anti-drug Ab from sample. Results were evaluated by a cut-off control. Samples with optical density higher than that of the specific drug cut off were considered positive.

\section{Statistical analysis}

Unless otherwise indicated, values were expressed as mean \pm standard deviation. Comparison of continuous variables between two groups was performed by the non-parametric MannWhitney rank sum test. Discrete variables were compared, by group, using chi square test. When the frequency was $<5$, the Fisher's exact test was used. Statistical significance was defined as a two-tailed $p$ value of $<0.05$.

\section{Results}

\section{Characteristics of the study population}

The study enrolled a total of 192 patients of which $51 \%$ were women. The mean age at the time of blood collection was $60 \pm 12$ years for women and $55 \pm 13$ years for men.

The underlying diseases of these patients that warranted anti-TNFa treatment were: $\mathrm{RA}(\mathrm{N}=77 ; 40 \%)$ and $\mathrm{SpA}(\mathrm{N}=115$; $60 \%)$. The proportion of patients treated with IFX, ADA and ETN, was $32 \%(\mathrm{~N}=62), 33 \%(\mathrm{~N}=64)$ and $35 \%(\mathrm{~N}=66)$, respectively. 
The mean duration of therapy at the time of blood collection was $56 \pm 35,42 \pm 36$ and $57 \pm 39$ months for IFX, ADA and ETN users, respectively.

Table 1 shows the gender and age distribution of the studied patients. As shown, male subjects are predominant in the $18-45$ age group, representing $66.7 \%$ of the patients, while an opposite figure is found in the $>67$ age group where women represent $60.9 \%$ of the patients. No difference in gender distribution is observed in the 46-66 age group. Subdividing the 18-45 and $>67$ age groups by gender and disease (Table 2), it was observed that in the 18-45 age group the prevalence of $S p A$ is significantly higher $(p=0.01)$ than RA in male patients, while in the $>67$ years group the prevalence of RA is lightly higher (64.3\%) in female patients. Taking into account gender and disease distribution of the 192 patients, women represent $64.9 \%$ (50 out 77) of RA patients with a 1.9:1 female/male ratio.

Drug and anti-drug antibody in RA and SpA patients The relationship between serum drug levels and anti-drug $A b$ presence for each drug treatment was evaluated in both RA and SpA patients (Table 3). Antibodies against IFX were demonstrated in 12 (19.4\%) patients, 5 RA and 7 SpA patients; anti-ADA Ab were detected only in $3(4.7 \%)$ patients all belonging to the RA group; anti-ETN Ab were present in $6(9 \%)$ patients, 4 RA and $2 \mathrm{SpA}$. As shown in Table 3, patients who developed anti-drug Ab don't had drug levels significantly different from patients who did not developed anti-drug $A b$.

Serum drug level, anti-drug Ab status and clinical response in RA and SpA patients

In order to analyze the relationship between serum drug levels and clinical response, RA and SpA patients were divided
Table 1. Patient gender distribution for age groups.

\begin{tabular}{lllll}
\hline \multirow{5}{*}{ Age group } & \multicolumn{3}{c}{ Pemalients } \\
\cline { 2 - 5 } & $\mathbf{N}^{\circ}$ & Prevalence \% & $\mathbf{N}^{\circ}$ & Prevalence \% \\
\hline 18-45 years & 13 & 33.3 & 26 & 66.7 \\
46-54 years & 24 & 49.0 & 25 & 51.0 \\
55-66 years & 33 & 56.9 & 25 & 43.1 \\
$>$ 67 years & 28 & 60.9 & 18 & 39.1 \\
\hline
\end{tabular}

Table 2. Disease distribution for gender.

\begin{tabular}{llllll}
\hline \multirow{2}{*}{ Age group } & \multirow{2}{*}{ Disease } & \multicolumn{5}{c}{ Female } & & Male \\
\cline { 3 - 6 } & & $\mathbf{N}^{\circ}$ & Prevalence $\%$ & $\mathbf{N}^{\circ}$ & Prevalence \% \\
\hline 18->67 years & RA & 50 & 51 & 27 & 28.7 \\
& SpA & 48 & 49 & 67 & 71.3 \\
\hline 18-45 years & RA & 5 & 38.4 & 3 & 11.5 \\
& SpA & 8 & 61.6 & 23 & 88.5 \\
\hline 46-54 years & RA & 7 & 29.1 & 5 & 20 \\
& SpA & 17 & 70.9 & 20 & 80 \\
\hline $55-66$ years & RA & 20 & 54.1 & 8 & 32 \\
& SpA & 13 & 41.9 & 17 & 68 \\
\hline$>67$ years & RA & 18 & 64.3 & 11 & 61.1 \\
& SpA & 10 & 35.7 & 7 & 38.9 \\
\hline
\end{tabular}

into three groups according to DAS28 and BASDAI scores, respectively. As shown in Table 4, there were no significant differences in serum drug levels between subjects of the three DAS28 and BASDAI categories both in RA and SpA patients. Moreover, for each drug treatment no significant difference was observed in the clinical response of anti-drug Ab positive and negative subjects in each disease group (Table 5).

Table 3. Relationship between serum drug levels and anti-drug Ab in between RA and SpA patients.

\begin{tabular}{|c|c|c|c|c|c|c|}
\hline \multicolumn{7}{|c|}{ INFLIXIMAB } \\
\hline & \multicolumn{3}{|c|}{ RA patients (N.18) } & \multicolumn{3}{|c|}{ SpA patients(N. 44) } \\
\hline & $\begin{array}{l}\text { Anti-IFX Ab } \\
\text { Positive (N. 5) }\end{array}$ & $\begin{array}{l}\text { Anti-IFX Ab } \\
\text { Negative (N.13) }\end{array}$ & P-value & $\begin{array}{l}\text { Anti-IFX Ab } \\
\text { Positive (N. 7) }\end{array}$ & $\begin{array}{l}\text { Anti-IFX Ab } \\
\text { Negative (N. 37) }\end{array}$ & P-value \\
\hline $\begin{array}{l}\text { IFX serum concentration } \\
\text { Mean } \pm \text { SD (ng/ml) }\end{array}$ & $5.51 \pm 8.71$ & $13.75 \pm 13.73$ & 0.49 & $3.68 \pm 4.11$ & $15.53 \pm 18.23$ & 0.25 \\
\hline \multicolumn{7}{|c|}{ ADALIMUMAB } \\
\hline & \multicolumn{3}{|c|}{ RA patients (N.27) } & \multicolumn{3}{|c|}{ SpA patients (N. 37) } \\
\hline & $\begin{array}{l}\text { Anti-ADA Ab } \\
\text { Positive (N. 3) }\end{array}$ & $\begin{array}{l}\text { Anti-ADA Ab } \\
\text { Negative (N. 24) }\end{array}$ & P-value & $\begin{array}{l}\text { Anti-ADA Ab } \\
\text { Positive (N. 0) }\end{array}$ & $\begin{array}{l}\text { Anti-ADA Ab } \\
\text { Negative (N. } \\
\text { 37) }\end{array}$ & P-value \\
\hline $\begin{array}{l}\text { ADA serum concentration } \\
\text { Mean } \pm \mathrm{SD}(\mathrm{ng} / \mathrm{ml})\end{array}$ & $18.19 \pm 30.64$ & $40.87 \pm 60.11$ & 0.73 & -- & $40.65 \pm 30.51$ & -- \\
\hline \multicolumn{7}{|c|}{ ETANERCEPT } \\
\hline & \multicolumn{3}{|c|}{ RA patients (N.32) } & \multicolumn{3}{|c|}{ SpA patients (N. 34) } \\
\hline & $\begin{array}{l}\text { Anti-ETN Ab } \\
\text { Positive (N. 4) }\end{array}$ & $\begin{array}{l}\text { Anti-ETN Ab } \\
\text { Negative (N. 28) }\end{array}$ & P-value & $\begin{array}{l}\text { Anti-ETN Ab } \\
\text { Positive (N. 2) }\end{array}$ & $\begin{array}{l}\text { Anti-ETN Ab } \\
\text { Negative (N. 32) }\end{array}$ & P-value \\
\hline $\begin{array}{l}\text { ETN serum concentration } \\
\text { Mean } \pm \text { SD }(\mu \mathrm{g} / \mathrm{ml})\end{array}$ & $2.71 \pm 1.69$ & $3.89 \pm 0.58$ & 0.43 & $4 \pm 0$ & $3.55 \pm 0.98$ & 0.50 \\
\hline
\end{tabular}


Table 4. Relationship between serum drug levels and clinical efficacy in between RA and SpA patients.

\begin{tabular}{|c|c|c|c|c|c|c|c|}
\hline \multicolumn{8}{|c|}{ INFLIXIMAB } \\
\hline \multicolumn{4}{|c|}{ RA patients [N.18] } & \multicolumn{4}{|c|}{ SpA patients [N.44] } \\
\hline DAS28 & $\begin{array}{l}\text { Number of } \\
\text { patients }\end{array}$ & $\begin{array}{l}\text { Drug concentration } \\
\text { Mean } \pm S D(\mathrm{ng} / \mathrm{ml})\end{array}$ & P-value & BASDAI & $\begin{array}{l}\text { Number of } \\
\text { patients }\end{array}$ & $\begin{array}{l}\text { Drug concentration } \\
\text { Mean } \pm S D(n g / m l)\end{array}$ & P-value \\
\hline$\leq 3.2$ & 8 & $9.95 \pm 11.33$ & 0.69 & $\leq 2$ & 15 & $10.77 \pm 11.06$ & 0.43 \\
\hline$\leq 5.1$ & 7 & $7.64 \pm 8.34$ & 0.63 & $\leq 4$ & 21 & $13.08 \pm 11.72$ & 0.36 \\
\hline$>5.1$ & 3 & $24.42 \pm 20.87$ & 0.43 & $>4$ & 8 & $20.73 \pm 33.60$ & 0.61 \\
\hline \multicolumn{8}{|c|}{ ADALIMUMAB } \\
\hline \multicolumn{4}{|c|}{ RA patients [N.27] } & \multicolumn{4}{|c|}{ SpA patients [N.37] } \\
\hline DAS28 & $\begin{array}{l}\text { Number of } \\
\text { patients }\end{array}$ & $\begin{array}{l}\text { Drug concentration } \\
\text { Mean } \pm S D(n g / m l)\end{array}$ & P-value & BASDAI & $\begin{array}{l}\text { Number of } \\
\text { patients }\end{array}$ & $\begin{array}{l}\text { Drug concentration } \\
\text { Mean } \pm S D(\mathrm{ng} / \mathrm{ml})\end{array}$ & P-value \\
\hline$\leq 3.2$ & 15 & $42.49 \pm 55.37$ & 0.29 & $\leq 2$ & 22 & $46.31 \pm 29.12$ & 0.13 \\
\hline$\leq 5.1$ & 11 & $36.13 \pm 64.56$ & 0.15 & $\leq 4$ & 9 & $32.09 \pm 21.86$ & 0.13 \\
\hline$>5.1$ & 1 & 0.5 & 0.27 & $>4$ & 6 & $57.42 \pm 43.38$ & 0.35 \\
\hline \multicolumn{8}{|c|}{ ETANERCEPT } \\
\hline \multicolumn{4}{|c|}{ RA patients [N.32] } & \multicolumn{4}{|c|}{ SpA patients [N.34] } \\
\hline DAS28 & $\begin{array}{l}\text { Number of } \\
\text { patients }\end{array}$ & $\begin{array}{l}\text { Drug concentration } \\
\text { Mean } \pm \mathrm{SD}(\mu \mathrm{g} / \mathrm{ml})\end{array}$ & P-value & BASDAI & $\begin{array}{l}\text { Number of } \\
\text { patients }\end{array}$ & $\begin{array}{l}\text { Drug concentration } \\
\text { Mean } \pm S D(\mu \mathrm{g} / \mathrm{ml})\end{array}$ & P-value \\
\hline$\leq 3.2$ & 25 & $3.81 \pm 0.68$ & 0.92 & $\leq 2$ & 12 & $3.24 \pm 1.26$ & 0.71 \\
\hline$\leq 5.1$ & 5 & $3.28 \pm 1.59$ & 0.84 & $\leq 4$ & 13 & $3.79 \pm 0.67$ & 0.66 \\
\hline$>5.1$ & 2 & $4.0 \pm 0$ & 0.95 & $>4$ & 9 & $3.74 \pm 0.78$ & 0.92 \\
\hline
\end{tabular}

Table 5. Relationship between anti-drug Ab status and clinical efficacy in between RA and SpA patients.

\begin{tabular}{|c|c|c|c|c|c|c|c|}
\hline \multicolumn{8}{|c|}{ INFLIXIMAB } \\
\hline \multicolumn{4}{|c|}{ RA patients (N.18) } & \multicolumn{4}{|c|}{ SpA patients (N.44) } \\
\hline & $\begin{array}{l}\text { Anti-IFX Ab } \\
\text { Positive (N. 5) }\end{array}$ & $\begin{array}{l}\text { Anti-IFX Ab } \\
\text { Negative (N.13) }\end{array}$ & P-value & -- & $\begin{array}{l}\text { Anti-IFX Ab } \\
\text { Positive (N. 7) }\end{array}$ & $\begin{array}{l}\text { Anti-IFX Ab } \\
\text { Negative (N. 37) }\end{array}$ & P-value \\
\hline DAS28 Mean \pm SD & $4.29 \pm 2.13$ & $3.57 \pm 1.45$ & 0.85 & BASDAI Mean \pm SD & $2.88 \pm 1.83$ & $2.29 \pm 1.62$ & 0.40 \\
\hline \multicolumn{8}{|c|}{ ADALIMUMAB } \\
\hline \multicolumn{4}{|c|}{ RA patients (N.27) } & \multicolumn{4}{|c|}{ SpA patients (N.37) } \\
\hline & $\begin{array}{l}\text { Anti-ADA Ab } \\
\text { Positive (N. 3) }\end{array}$ & $\begin{array}{l}\text { Anti-ADA Ab } \\
\text { Negative (N.24) }\end{array}$ & P-value & -- & $\begin{array}{l}\text { Anti-ADA Ab } \\
\text { Positive (N. 0) }\end{array}$ & $\begin{array}{l}\text { Anti-ADA Ab } \\
\text { Negative (N. 37) }\end{array}$ & P-value \\
\hline DAS28 Mean \pm SD & $4.54 \pm 2.07$ & $3.10 \pm 1.03$ & 0.63 & BASDAI Mean \pm SD & -- & $2.62 \pm 3.07$ & -- \\
\hline \multicolumn{8}{|c|}{ ETANERCEPT } \\
\hline \multicolumn{4}{|c|}{ RA patients (N.32) } & \multicolumn{4}{|c|}{ SpA patients (N.34) } \\
\hline & $\begin{array}{l}\text { Ant-ETN Ab } \\
\text { Positive (N. 4) }\end{array}$ & $\begin{array}{l}\text { Ant-ETN Ab } \\
\text { Negative (N.28) }\end{array}$ & P-value & -- & $\begin{array}{l}\text { Ant-ETN Ab } \\
\text { Positive (N. 2) }\end{array}$ & $\begin{array}{l}\text { Ant-ETN Ab } \\
\text { Negative (N. 32) }\end{array}$ & P-value \\
\hline DAS28 Mean \pm SD & $2.72 \pm 1.03$ & $2.88 \pm 1.10$ & 0.57 & BASDAI Mean \pm SD & $1.95 \pm 0.91$ & $3.05 \pm 1.90$ & 0.78 \\
\hline
\end{tabular}

Serum drug level, anti-drug Ab status and clinical re- the difference was not significant $(p=0.11)$. sponse in RA and SpA patients treated with anti-TNFa monotherapy or concomitant MTX therapy

In order to verify the effects of the concomitant use of MTX, RA and SpA patients were divided into MTX users and MTX non-users, and serum drug levels, anti-drug $A b$ status and clinical response were analyzed (Table 6). Data show that for each drug treatment there was no significant difference in serum drug level and clinical status between MTX users and MTX non-users. Moreover, anti-drug Ab positive subjects were present in both MTX groups with no significant difference; in SpA patients under IFX therapy, $26 \%$ of MTX non-users developed anti-drug Ab compared to $5.6 \%$ of MTX users but

\section{Discussion}

TNF blockers represent a breakthrough in the management of rheumatic diseases, including RA and SpA, having a relevant effect on their clinical course and prognosis. These drugs, however, have some limitations due to primary or secondary loss of efficacy. The latter maybe determined by the phenomenon of immunogenicity $[\mathbf{2 6 , 2 7 ]}$ which lowers the blood levels of effective drug and consequently decreases the clinical response.

The aim of this study was to evaluate the relevance of drug and anti-drug antibody detection on the clinical management 
Table 6. Relationship between MTX therapy and clinical efficacy, serum drug levels and anti-drug Ab status in between RA and SpA patients.

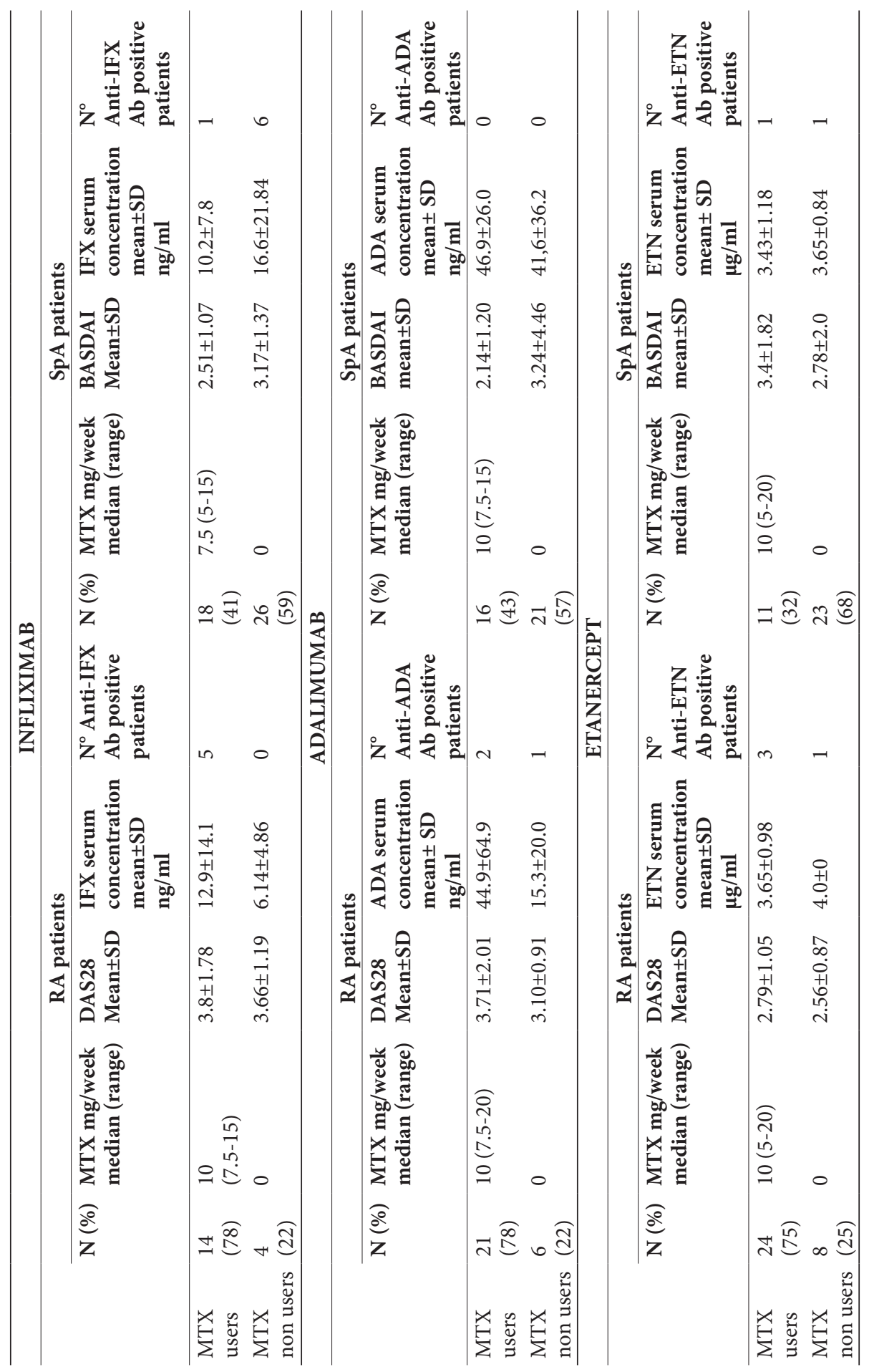

of RA and SpA patients treated with anti-TNFa biologics.

The study population included 192 patients of which 98 were females and 94 males. Fifty-two \% of female population was affected by RA and $48 \%$ by SpA, while only $28.8 \%$ of male patients was RA; the incidence of RA, as expected [28], is higher in the female population with a ratio female/male 2:1. When the population was subdivided in age groups, it was observed that in the intermediate age groups (46-54 and 55-66 years) the number of female and male patients was equivalent, while, in the $18-45$ group, males were predominant with a prevalence 
of $67 \%$ and in the $\geq 67$ years females reached $61 \%$. In the $18-45$ group the $\mathrm{SpA}$ is the disease with the highest prevalence of $79.5 \%$; in particular, in the male population SpA is significantly higher $(74 \% \mathrm{p}=0.01)$ than RA (26\%) while in females the two diseases are roughly equivalent. Moreover the female:male ratio of patients affected by SpA is 1:3 in agreement with data from the literature that show a higher prevalence of SpA in young males with a ratio female:male of 1:3 [29]. In the $\geq 67$ age group females and males are $60.9 \%$ and $39.1 \%$ respectively. In the female group RA shows a prevalence of $64.3 \%$ and SpA $35.7 \%$. A higher prevalence of RA in females is reported in the literature: in women RA develops between 30- 50 years with an incidence 3-5 times higher in females than males and this incidence tends to decrease with increasing age [29]. Therefore our results demonstrate that the study population is epidemiologically representative of the two autoimmune diseases both for sex and for age distribution.

In the literature, the percentage of patients who develop anti-drug Ab may vary by sex, different autoimmune inflammatory diseases and among different anti-TNF treatments. In this study, patients with anti-drug Ab were 21/192 (10.9\%), 8 females and 13 males (data not shown) indicating that there is no correlation between drug immunogenicity and sex of the patient in contrast with what it was described by Mok [5] who reported a higher prevalence of anti-drug $A b$ in females than in males.

Anti-drug $\mathrm{Ab}$ are generally reported as detected in up to one third of RA and about $25 \%$ of SpA patients [2,30-33]. Chimericdrugs (mouse-human), such as IFX, have a greater likelihood of inducing anti-drug Abs production compared to fully human antibodies [34,35]. Not all patients treated with anti-TNF therapy develop anti-drug $\mathrm{Ab}$ and this seems to be multi-factorial: the treatment, the patient, external factors [33]. We have found that the phenomenon of immunogenicity is present for all used drug treatments in RA patients while in SpA patients is limited to IFX and ETN. Anti-IFX Ab were present in $28 \%$ of RA and $16 \%$ of SpA patients in accordance with previous studies revealing anti-IFX Ab from 12 to $44 \%$ in RA [36] and from 6 to $61 \%$ in SpA [37]. Anti-ETN Ab were found in $12.5 \%$ of RA and $6 \%$ of SpA patients and anti-ADA Ab in 11\% of RA patients; ETN is considered the less immunogenic one and only few studies [38] report the presence of anti-ETN Ab in SpA patients. In our hands, on the contrary, ADA is the treatment that shows the lowest rate of anti-drug Ab (4.7\%) compared to IFX (19.4\%) and ETN (9.0\%).

We did not find statistically significant differences between serum TNFa blockers concentrations in RA and SpA patients that did and did not develop anti-drug Ab, although in previous studies low serum drug levels resulted inversely correlated with anti-drug Ab presence [5]. Moreover, no significant differences were found between drug levels and clinical status in RA and SpA classified by DAS28 or BADSAI score; furthermore, no significant difference was observed in the clinical response of anti-drug $\mathrm{Ab}$ positive and negative subjects of each disease group. Most of the studies refer that therapy failure occurred more frequently in positive anti-drug Ab patients $[3,32,37,39]$, although there are previous reports which did not find a similar relation [40-42]. It is also reported that the concomitant use of MTX with anti-TNFa drugs reduces the incidence of anti-drug Ab [6,36]; in our study, in agreement with opposite results $[13,39]$ concomitant MTX therapy was irrelevant on anti-drug Ab development.

A possible explanation of the discrepancies observed in the present study could be found in the recruitment criteria of the patients population; the patients of this study represent a consecutive population in the normal daily clinical setting without selection based on the presence or absence of antidrug Ab. Moreover, in order to simulate more precisely the normal clinical use of these diagnostic tools in real clinical practice it has been decided to collect blood only once.

It has been described that anti-TNF Ab titres can decrease and increase over time, and vice versa $[37,43,44]$, causing a gradual increase in incidence over time when anti-drug $A b$ status is presented cumulatively, but not when assessed at each time point independently [44]. This explains why the time of measuring can influence the relevance and interpretation of anti-drug Ab status. It is therefore very difficult to draw a well-defined statement regarding the relationship between clinical response and anti-drug Ab measurement in clinical practice.

\section{Conclusion}

Our results indicate that the link between either serum drug levels or anti-drug $\mathrm{Ab}$ and clinical response is not as strong as previously assumed. This argues against the use of these parameters in monitoring drug efficacy. Although testing immunogenicity in clinical trials is standard practice and may yield interesting scientific insights, in clinical practice the real added value of the presence or absence of anti-drug $A b$ and the detection serum drug levels in an individual patient remains to be demonstrated.

\section{Competing interests}

The authors declare that they have no competing interests.

\section{Acknowledgement and funding}

This study was supported by an unconditioned research grant from Pfizer Inc.

\section{Publication history}

Editor: Pier Luigi Meroni, University of Milan, Italy. Received: 03-Jan-2017 Final Revised: 13-Feb-2017 Accepted: 27-Mar-2017 Published: 11-Apr-2017

\section{References}

1. Kneepkens EL, Krieckaert CL, van der Kleij D, Nurmohamed MT, van der Horst-Bruinsma IE, Rispens T and Wolbink GJ. Lower etanercept levels are associated with high disease activity in ankylosing spondylitis patients at 24 weeks of follow-up. Ann Rheum Dis. 2015; 74:1825-9. I Article I PubMed 
2. Kneepkens EL, Wei JC, Nurmohamed MT, Yeo KJ, Chen CY, van der HorstBruinsma IE, van der Kleij D, Rispens T, Wolbink $G$ and Krieckaert CL. Immunogenicity, adalimumab levels and clinical response in ankylosing spondylitis patients during 24 weeks of follow-up. Ann Rheum Dis. 2015; 74:396-401. | Article | PubMed

3. de Vries MK, Wolbink GJ, Stapel SO, de Groot ER, Dijkmans BA, Aarden LA and van der Horst-Bruinsma IE. Inefficacy of infliximab in ankylosing spondylitis is correlated with antibody formation. Ann Rheum Dis. 2007; 66:133-4. | Article | PubMed Abstract | PubMed FullText

4. Mazilu D, Opris D, Gainaru C, Iliuta M, Apetrei N, Luca G, Borangiu A, Gudu T, Peltea A, Groseanu L, Constantinescu C, Saulescu I, Bojinca V, Balanescu A, Predeteanu D and lonescu R. Monitoring drug and antidrug levels: a rational approach in rheumatoid arthritis patients treated with biologic agents who experience inadequate response while being on a stable biologic treatment. Biomed Res Int. 2014; 2014:702701. | Article | PubMed Abstract | PubMed FullText

5. Mok CC, van der Kleij D and Wolbink GJ. Drug levels, anti-drug antibodies, and clinical efficacy of the anti-TNFalpha biologics in rheumatic diseases. Clin Rheumatol. 2013; 32:1429-35. | Article | PubMed

6. Bartelds $G M$, Krieckaert C L M, Nurmohamed M T, van Schouwenburg PA and Lems WF. Development of antidrug antibodies against adalimumab and association with disease activity and treatment failure during longterm follow-up. The Journal of the American Medical Association. 2011; 305:1460-1468. | Article

7. Hoshino M, Yoshio T, Onishi S and Minota S. Influence of antibodies against infliximab and etanercept on the treatment effectiveness of these agents in Japanese patients with rheumatoid arthritis. Mod Rheumatol. 2012; 22:532-40. | Article | PubMed

8. de Vries MK, van der Horst-Bruinsma IE, Nurmohamed MT, Aarden LA, Stapel SO, Peters MJ, van Denderen JC, Dijkmans BA and Wolbink GJ. Immunogenicity does not influence treatment with etanercept in patients with ankylosing spondylitis. Ann Rheum Dis. 2009; 68:531-5. I Article I PubMed

9. Dore RK, Mathews S, Schechtman J, Surbeck W, Mandel D, Patel A, Zhou $L$ and Peloso $P$. The immunogenicity, safety, and efficacy of etanercept liquid administered once weekly in patients with rheumatoid arthritis. Clin Exp Rheumatol. 2007; 25:40-6. | Article | PubMed

10. Wolbink GJ, Vis M, Lems W, Voskuyl AE, de Groot E, Nurmohamed MT, Stapel S, Tak PP, Aarden L and Dijkmans B. Development of antiinfliximab antibodies and relationship to clinical response in patients with rheumatoid arthritis. Arthritis Rheum. 2006; 54:711-5. | Article | PubMed

11. Bender NK, Heilig CE, Droll B, Wohlgemuth J, Armbruster FP and Heilig $B$. Immunogenicity, efficacy and adverse events of adalimumab in RA patients. Rheumatol Int. 2007; 27:269-74. | Article | PubMed

12. Du Pan SM, Dehler S, Ciurea A, Ziswiler HR, Gabay C and Finckh A. Comparison of drug retention rates and causes of drug discontinuation between anti-tumor necrosis factor agents in rheumatoid arthritis. Arthritis Rheum. 2009; 61:560-8. | Article | PubMed

13. Perez-Guijo VC, Cravo AR, Castro Mdel C, Font P, Munoz-Gomariz E and Collantes-Estevez $E$. Increased efficacy of infliximab associated with methotrexate in ankylosing spondylitis. Joint Bone Spine. 2007; 74:2548. | Article | PubMed

14. Mulleman D, Lauferon F, Wendling D, Ternant D, Ducourau E, Paintaud $G$ and Goupille P. Infliximab in ankylosing spondylitis: alone or in combination with methotrexate? A pharmacokinetic comparative study. Arthritis Res Ther. 2011; 13:R82. | Article | PubMed Abstract | PubMed FullText

15. Breban M, Ravaud P, Claudepierre P, Baron G, Henry YD, Hudry C, Euller-Ziegler L, Pham T, Solau-Gervais E, Chary-Valckenaere I, Marcelli C, Perdriger A, Le Loet X, Wendling D, Fautrel B, Fournie B, Combe B, Gaudin P, Jousse S, Mariette X, Baleydier A, Trape G and Dougados M. Maintenance of infliximab treatment in ankylosing spondylitis: results of a one-year randomized controlled trial comparing systematic versus on-demand treatment. Arthritis Rheum. 2008; 58:88-97. | Article | PubMed
16. Sampaio-Barros PD, Costallat LT, Bertolo MB, Neto JF and Samara AM Methotrexate in the treatment of ankylosing spondylitis. Scand J Rheumatol. 2000; 29:160-2. | PubMed

17. Maini R N, Breedveld F C, Kalden J R, Smolen JS and Davis D. Therapeutic efficacy of multiple intravenous infusions of anti-tumour necrosis factor $\alpha$ monoclonal antibody combined with low-dose weekly methotrexate in rheumatoid arthritis. Arthritis \& Rheumatism. 1998; 41:1552-1563. | Article

18. Lipsky PE, van der Heijde DM, St Clair EW, Furst DE, Breedveld FC, Kalden JR, Smolen JS, Weisman M, Emery P, Feldmann M, Harriman GR and Maini RN. Infliximab and methotrexate in the treatment of rheumatoid arthritis. Anti-Tumor Necrosis Factor Trial in Rheumatoid Arthritis with Concomitant Therapy Study Group. N Engl J Med. 2000; 343:1594-602. I Article I PubMed

19. St Clair EW, Wagner CL, Fasanmade AA, Wang B, Schaible T, Kavanaugh $A$ and Keystone EC. The relationship of serum infliximab concentrations to clinical improvement in rheumatoid arthritis: results from ATTRACT, a multicenter, randomized, double-blind, placebo-controlled trial. Arthritis Rheum. 2002; 46:1451-9. | Article | PubMed

20. Arora A, Mahajan A, Spurden D, Boyd H and Porter D. Long-Term Drug Survival of TNF Inhibitor Therapy in RA Patients: A Systematic Review of European National Drug Registers. Int J Rheumatol. 2013; 2013:764518. | Article | PubMed Abstract | PubMed FullText

21. Fabbroni M, Cantarini L, Caso F, Costa L, Pagano VA, Frediani B, Manganelli $S$ and Galeazzi M. Drug retention rates and treatment discontinuation among anti-TNF-alpha agents in psoriatic arthritis and ankylosing spondylitis in clinical practice. Mediators Inflamm. 2014; 2014:862969. | Article | PubMed Abstract | PubMed FullText

22. Garces S, Demengeot J and Benito-Garcia E. The immunogenicity of antiTNF therapy in immune-mediated inflammatory diseases: a systematic review of the literature with a meta-analysis. Ann Rheum Dis. 2013; 72:1947-55. | Article | PubMed

23. Prevoo ML, van 't Hof MA, Kuper HH, van Leeuwen MA, van de Putte LB and van Riel PL. Modified disease activity scores that include twentyeight-joint counts. Development and validation in a prospective longitudinal study of patients with rheumatoid arthritis. Arthritis Rheum. 1995; 38:44-8. | Article | PubMed

24. Garrett S, Jenkinson T, Kennedy LG, Whitelock H, Gaisford P and Calin A. A new approach to defining disease status in ankylosing spondylitis: the Bath Ankylosing Spondylitis Disease Activity Index. J Rheumatol. 1994; 21:2286-91. | PubMed

25. van Gestel AM, Prevoo ML, van 't Hof MA, van Rijswijk MH, van de Putte LB and van Riel PL. Development and validation of the European League Against Rheumatism response criteria for rheumatoid arthritis. Comparison with the preliminary American College of Rheumatology and the World Health Organization/International League Against Rheumatism Criteria. Arthritis Rheum. 1996; 39:34-40. | Article | PubMed

26. Meroni PL, Valentini G, Ayala F, Cattaneo A and Valesini G. New strategies to address the pharmacodynamics and pharmacokinetics of tumor necrosis factor (TNF) inhibitors: A systematic analysis. Autoimmun Rev. 2015; 14:812-29. | Article | PubMed

27. Zisapel M, Zisman D, Madar-Balakirski N, Arad U, Padova H, Matz H, Maman-Sarvagyl H, Kaufman I, Paran D, Feld J, Litinsky I, Wigler I, Caspi $\mathrm{D}$ and Elkayam $\mathrm{O}$. Prevalence of TNF-alpha blocker immunogenicity in psoriatic arthritis. J Rheumatol. 2015; 42:73-8. | Article | PubMed

28. Kvien TK, Uhlig T, Odegard S and Heiberg MS. Epidemiological aspects of rheumatoid arthritis: the sex ratio. Ann N Y Acad Sci. 2006; 1069:212-22. | Article | PubMed

29. Bakland $G$ and Nossent HC. Epidemiology of spondyloarthritis: a review. Curr Rheumatol Rep. 2013; 15:351. | Article | PubMed

30. de Vries MK, Wolbink GJ, Stapel SO, de Vrieze H, van Denderen JC, Dijkmans BA, Aarden LA and van der Horst-Bruinsma IE. Decreased clinical response to infliximab in ankylosing spondylitis is correlated with anti-infliximab formation. Ann Rheum Dis. 2007; 66:1252-4. | Article | PubMed Abstract | PubMed FullText

31. Pascual-Salcedo D, Plasencia C, Ramiro S, Nuno L, Bonilla G, Nagore 
D, Ruiz Del Agua A, Martinez A, Aarden L, Martin-Mola E and Balsa A. Influence of immunogenicity on the efficacy of long-term treatment with infliximab in rheumatoid arthritis. Rheumatology (Oxford). 2011; 50:1445-52. | Article | PubMed

32. Plasencia C, Pascual-Salcedo D, Garcia-Carazo S, Lojo L, Nuno L, Villalba A, Peiteado D, Arribas F, Diez J, Lopez-Casla MT, Martin-Mola E and Balsa A. The immunogenicity to the first anti-TNF therapy determines the outcome of switching to a second anti-TNF therapy in spondyloarthritis patients. Arthritis Res Ther. 2013; 15:R79. | Article | PubMed Abstract | PubMed FullText

33. Plasencia C, Pascual-Salcedo D, Nuno L, Bonilla G, Villalba A, Peiteado D, Diez J, Nagore D, del Agua AR, Moral R, Martin-Mola E and Balsa A. Influence of immunogenicity on the efficacy of longterm treatment of spondyloarthritis with infliximab. Ann Rheum Dis. 2012; 71:1955-60. | Article | PubMed

34. Anderson PJ. Tumor necrosis factor inhibitors: clinical implications of their different immunogenicity profiles. Semin Arthritis Rheum. 2005; 34:19-22. | Article | PubMed

35. Emi Aikawa N, de Carvalho JF, Artur Almeida Silva C and Bonfa E. Immunogenicity of Anti-TNF-alpha agents in autoimmune diseases. Clin Rev Allergy Immunol. 2010; 38:82-9. | Article | PubMed

36. Arstikyte I, Kapleryte G, Butrimiene I and Venalis A. Influence of Immunogenicity on the Efficacy of Long-Term Treatment with TNF alpha Blockers in Rheumatoid Arthritis and Spondyloarthritis Patients. Biomed Res Int. 2015; 2015:604872. | Article | PubMed Abstract | PubMed FullText

37. Arends S, Lebbink HR, Spoorenberg A, Bungener LB, Roozendaal C, van der Veer E, Houtman PM, Griep EN, Limburg PC, Kallenberg CG, Wolbink $\mathrm{GJ}$ and Brouwer $\mathrm{E}$. The formation of autoantibodies and antibodies to TNF-alpha blocking agents in relation to clinical response in patients with ankylosing spondylitis. Clin Exp Rheumatol. 2010; 28:661-8. | Article I PubMed

38. Hsu L, Snodgrass BT and Armstrong AW. Antidrug antibodies in psoriasis: a systematic review. Br J Dermatol. 2014; 170:261-73. | Article | PubMed

39. Ducourau E, Mulleman D, Paintaud G, Miow Lin DC, Lauferon F, Ternant $\mathrm{D}$, Watier $\mathrm{H}$ and Goupille P. Antibodies toward infliximab are associated with low infliximab concentration at treatment initiation and poor infliximab maintenance in rheumatic diseases. Arthritis Res Ther. 2011; 13:R105. | Article | PubMed Abstract | PubMed FullText

40. Baraliakos X, Listing J, Rudwaleit M, Brandt J, Alten R, Burmester G, Gromnica-Ihle E, Haibel H, Schewe S, Schneider M, Sorensen H, Zeidler H, Visvanathan S, Sieper J and Braun J. Safety and efficacy of readministration of infliximab after longterm continuous therapy and withdrawal in patients with ankylosing spondylitis. J Rheumatol. 2007; 34:510-5. | Article | PubMed

41. Krzysiek R, Breban M, Ravaud P, Prejean MV, Wijdenes J, Roy C, Henry YD, Barbey C, Trappe G, Dougados M and Emilie D. Circulating concentration of infliximab and response to treatment in ankylosing spondylitis: results from a randomized control study. Arthritis Rheum. 2009; 61:56976. | Article | PubMed

42. Paramarta JE and Baeten DL. Adalimumab serum levels and antidrug antibodies towards adalimumab in peripheral spondyloarthritis: no association with clinical response to treatment or with disease relapse upon treatment discontinuation. Arthritis Res Ther. 2014; 16:R160. | Article | PubMed Abstract | PubMed FullText

43. van Kuijk AW, de Groot M, Stapel SO, Dijkmans BA, Wolbink GJ and Tak PP. Relationship between the clinical response to adalimumab treatment and serum levels of adalimumab and anti-adalimumab antibodies in patients with psoriatic arthritis. Ann Rheum Dis. 2010; 69:624-5. | Article | PubMed

44. Hanauer SB, Wagner CL, Bala M, Mayer L, Travers S, Diamond RH, Olson $A, B a o W$ and Rutgeerts P. Incidence and importance of antibody responses to infliximab after maintenance or episodic treatment in Crohn's disease. Clin Gastroenterol Hepatol. 2004; 2:542-53. | Article | PubMed

\section{Citation:}

Lombardi S, Bernardoni C, Bertolucci D, Cecchetti R, Giorgio FD, Occhipinti G, Palagi A, Bertacca G, Giannelli I, Bonomi E, Friggeri M and Tartarelli G. Biologic therapies in rheumatic diseases: drug and anti-drug antibody levels and clinical efficacy. J Autoimmun Cell Response. 2017; 4:1. http://dx.doi.org/10.7243/2054-989X-4-1 